\title{
Influence of $\mathrm{MgO}$ on Low Temperature Reduction and Mineralogical Changes of Sinter in Simulated COREX Shaft Furnace Reducing Conditions
}

\author{
Deqing Zhu, Jianlei Chou, Benjing Shi * and Jian Pan \\ School of Minerals Processing and Bioengineering, Central South University, Changsha 410083, China; \\ dqzhu@csu.edu.cn (D.Z.); choujianlei@csu.edu.cn (J.C.); pjcsu@csu.edu.cn (J.P.) \\ * Correspondence: shi_benjing@126.com
}

Received: 2 April 2019; Accepted: 29 April 2019; Published: 1 May 2019

\begin{abstract}
COREX (Coal-Reduction-Extreme) smelting reduction process provides a sustainable developing way for ironmaking industry, but the sources of iron ore materials restrict its development in China. Meanwhile, the application of sinter, which is marked by low manufacture cost and overcapacity in China, to COREX furnace faced proportion limitation due to its worse low temperature reduction degradation performance. This work explored the influence of $\mathrm{MgO}$ content on the low-temperature $\left(550{ }^{\circ} \mathrm{C}\right)$ reduction of sinter in reducing conditions simulating COREX shaft furnace. The mineralogical change of sinter containing different content of $\mathrm{MgO}$ before and after reduction was analyzed by X-ray diffraction (XRD), optical microscopy, and scanning electron microscopy for revealing the action mechanism of $\mathrm{MgO}$ on the low-temperature-reduction of sinter. The results show that increasing $\mathrm{MgO}(1.36-3.10 \%)$ improved the low temperature reduction degradation performance of sinter, and decreased its reduction degree and reduction rate at low temperature. More $\mathrm{MgO}$ the sinter contained, less $\mathrm{Fe}_{2} \mathrm{O}_{3}$ and SFCA was observed in sinter. Meantime, less $\mathrm{Fe}_{2} \mathrm{O}_{3}$ was reduced and the generation of innerstress was restrained during reduction process. The improved RDI (reduction degradation index) in COREX process of sinter by increasing $\mathrm{MgO}$ content is a comprehensive result of lowering strength and inhibiting probable reduction of sinter.
\end{abstract}

Keywords: sinter; MgO; low temperature reduction; RDI; mineralogy; crack density; COREX

\section{Introduction}

COREX process is the earliest smelting reduction technology that established commercially and realized industrial production. When employing iron ore lumps and pellets as burden, $80-90 \%$ of fuel will be non-coking coal. This makes the COREX process less dependent on high-quality coking coal resources compared with traditional iron-making process in blast furnace (BF) [1-4]. However, the supply shortage and higher price of pellets, which brings about higher cost of hot metal by COREX process restrict its further development in China [5]. The Chinese steel mills innovatively proportioned sinter into the burden of COREX shaft furnace, on considering the surplus production capacity and relative lower fabricating cost of sinter [6]. However, the engineers found a high ratio of sinter in the burden caused problems in the shaft furnace, due to the worse low temperature reduction degradation performance of sinter compared with pellets and lumps. Thus, the proportion ratio of sinter in shaft furnace burden of COREX process was only $20-25 \%$.

Many researchers have investigated the reduction degradation of sinter and its mechanism in reducing condition simulating traditional blast furnace $(\mathrm{BF})$ process. The volumetric expansion generated by the reduction of hematite to magnetite was deemed as the main factor that causes reduction degradation [7-9]. Various elements and mineral phases composing the sinter have different 
effects on the low temperature reduction degradation performance of sinter, including the $\mathrm{MgO}$ content of sinter. Previous studies conducted in $\mathrm{BF}$ ironmaking process have pointed out that increasing $\mathrm{MgO}$ was beneficial to the RDI (reduction degradation index) of sinter. It restrains the transformation of $\mathrm{Fe}_{3} \mathrm{O}_{4}$ to $\mathrm{Fe}_{2} \mathrm{O}_{3}$ during sintering process and decreases the inner-stress generated during reduction [10-14]. Meantime, increasing $\mathrm{MgO}$ content made the reduction index (RI) declines. Considering the obvious differences in reducing conditions between the COREX and BF ironmaking processes, clarifying the effect of $\mathrm{MgO}$ on low temperature reduction of sinter in COREX reducing process has great directive significance for improving the RDI and good preparation of sinter for COREX shaft furnace.

In this work, the effect of $\mathrm{MgO}$ on low temperature reduction of sinter was studied at reducing condition simulating COREX shaft furnace. Simultaneously, the changes in mineralogy and microstructures of sinter with different levels of $\mathrm{MgO}$ content and their internal relation with RDI were analyzed for revealing the action mechanism of $\mathrm{MgO}$ content on the low temperature reduction degradation of sinter.

\section{Materials and Methods}

\subsection{Materials}

The sinter samples with different content of $\mathrm{MgO}$ used in this work were made from magnetite concentrates in laboratorial sinter pot. Several kinds of magnetite concentrates, a few secondary materials, fluxes, coke fines and water were weighted in certain weight proportion. They were mixed and granulated in a $600 \mathrm{~mm}$ diameter $\times 1400 \mathrm{~mm}$ length drum pelletizer. Then, the granules were loaded and sintered in a $180 \mathrm{~mm}$ diameter $\times 700 \mathrm{~mm}$ length sinter pot. The product sinter was tested for cold strength (tumble strength) according to ISO 3271-1995 [15], and then was crushed and sieved to 10-12.5 mm before reduction experiments. The chemical compositions of sinter samples were designed as follows: 56.08-57.02\% Fe $\mathrm{t}_{\text {total }}, 5.7-6.0 \% \mathrm{SiO}_{2}, 10.3-10.8 \% \mathrm{CaO}$, basicity $\left(\mathrm{CaO} / \mathrm{SiO}_{2}\right) 1.8,1.33 \% \mathrm{Al}_{2} \mathrm{O}_{3}, 1.1 \% \mathrm{TiO}$, and $1.36-3.10 \% \mathrm{MgO}$. The $\mathrm{MgO}$ content of sinter was adjusted by changing the ratio of dolomite proportioned to the sinter blends, leading to a little fluctuation of $\mathrm{Fe}_{\text {total }}$ and $\mathrm{SiO}_{2}$ content. Besides, a reducing agent used in this work was the standard cylinder gas including $\mathrm{CO}, \mathrm{H}_{2}, \mathrm{CO}_{2}$, and $\mathrm{N}_{2}$.

\subsection{Methods}

All the reduction experiments were conducted in a static gas-solid reaction apparatus as Figure 1 shows. The size of reduction tube is $75 \mathrm{~mm}$ diameter $\times 800 \mathrm{~mm}$ length, and it could resist the temperature above $900{ }^{\circ} \mathrm{C}$. The total mass of sinter sample for each test was $500 \mathrm{~g}$. The sinter samples were put into the reactor tube and heated from air temperature at a heating rate of $10^{\circ} \mathrm{C} / \mathrm{min}$ under shielding with pure $\mathrm{N}_{2}$ of $5 \mathrm{~L} / \mathrm{min}$. The temperature stopped rising after reaching $550{ }^{\circ} \mathrm{C}$, then the reducing gas consisted of $35 \% \mathrm{CO}, 50 \% \mathrm{CO}_{2}$, and $15 \% \mathrm{H}_{2}$, which is different from the standard reducing atmosphere $\left(20 \% \mathrm{CO}+20 \% \mathrm{CO}_{2}+60 \% \mathrm{~N}_{2}\right)$ in the traditional BF process, was introduced into the reactor tube with a gas flow of $13.3 \mathrm{~L} / \mathrm{min}$. After reducing for $30 \mathrm{~min}$, the reducing gas was replaced by $\mathrm{N}_{2}$ of $5 \mathrm{~L} / \mathrm{min}$ again and the reactor tube was removed from heat.

During reduction process, the sinter samples were on-line weighed by electronic balance and recorded by computer. The reduction degree (RD) of sinter at low temperature was calculated, refer to Equation (1):

$$
\mathrm{RD}=\left(\frac{0.111 w_{1}}{0.43 w_{2}}+\frac{m_{1}-m_{2}}{0.43 m_{1} w_{2}} \times 100\right) \times 100 \%
$$

where $m_{1}$ and $m_{2}$ mean the mass $(\mathrm{g})$ of sinter before and after reduction respectively, $w_{1}$ and $w_{2}$ mean the of $\mathrm{FeO}$ and $\mathrm{Fe}_{\text {total }}$ content (\%) of sinter, respectively, 0.111 and 0.43 are conversion coefficients for increment of oxygen during oxidation of $\mathrm{FeO}$ to $\mathrm{Fe}_{2} \mathrm{O}_{3}$ and $\mathrm{Fe}$ to $\mathrm{Fe}_{2} \mathrm{O}_{3}$ respectively. 


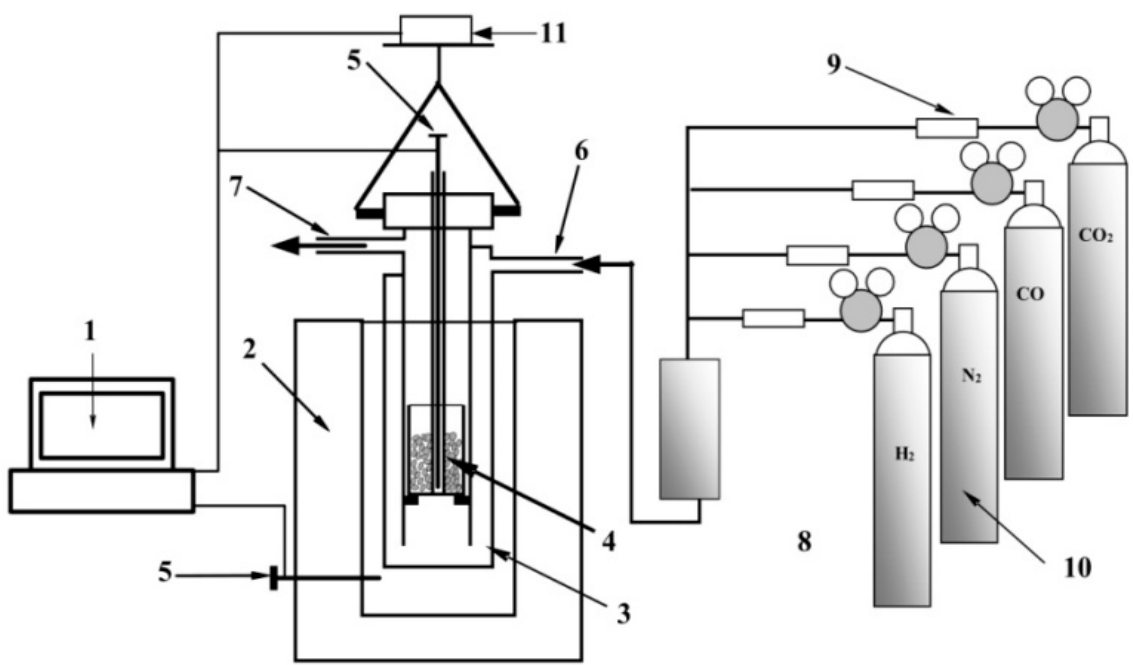

1-Computer, 2-Heater, 3-Reaction tube, 4-Sinter samples, 5-Thermocouple, 6-Gas inlet, 7-Gas outlet, 8-Mix tank, 9-Flowmeter, 10-Gas cylinder,11-Electronic balance

Figure 1. Schematics of experimental apparatus for reduction experiments.

After the sinter samples were cooled down to room temperature $\left(<30^{\circ} \mathrm{C}\right)$, they were taken out from reactor tube and charged into a tumbling drum $(130 \mathrm{~mm}$ diameter $\times 200 \mathrm{~mm}$ length) and rotated for $10 \mathrm{~min}$ at a speed of $30 \mathrm{rpm}$. After tumbling, the samples were sieved with $6.3 \mathrm{~mm}, 3.15 \mathrm{~mm}$, and $0.5 \mathrm{~mm}$ mesh, respectively, to determine the particle size distribution. The RDI was calculated by Equation (2) to Equation (4) as follows:

$$
\begin{aligned}
\mathrm{RDI}_{+6.3} & =\frac{M_{1}}{M} \times 100 \% \\
\mathrm{RDI}_{+3.15} & =\frac{M_{2}}{M} \times 100 \% \\
\mathrm{RDI}_{-0.5} & =\frac{M_{3}}{M} \times 100 \%
\end{aligned}
$$

where $M$ means the mass of sinter samples after reduction, $M_{1}$ and $M_{2}$ mean the mass of particles above $6.3 \mathrm{~mm}$ and $3.15 \mathrm{~mm}$ respectively after tumbling, $M_{3}$ means the mass of particles below $0.5 \mathrm{~mm}$.

Besides, the X-ray diffraction (XRD) (D/MAX, Osaka, Japan) and optical microscopy (Leica DMI5000M, Leica Camera AG, Wetzlar, Germany) were employed to analyze the changes of mineral composition and microstructure of sinter containing different levels of $\mathrm{MgO}$, before and after reduction. The quantitative analysis of mineral composition and cracks density for sinter sample was given by image analysis software QWin (Version 3.0) of Leica optical microscope [16]. The scanning electron microscopy (SEM) with energy dispersive spectrometer (EDS) (PhenomPro, Waltham, MA, USA) was used to determine the distribution of $\mathrm{MgO}$ in sinter.

\section{Results and Discussions}

\subsection{Effect of $\mathrm{MgO}$ on the Cold Strength and Low Temperature Reduction Degradation Performance of Sinter}

The cold strength (tumble index) of sinter samples with various $\mathrm{MgO}$ content and their RDI in condition simulated COREX shaft furnace are shown in Figure 2. Figure 2a suggests that the tumble strength of sinter decreased from $61.87 \%$ to $56.43 \%$ after the $\mathrm{MgO}$ content rose from natural $(1.36 \%)$ to $3.10 \%$, and the negative effect of increasing $\mathrm{MgO}$ content was more obvious before it reaches $1.80 \%$. Figure $2 \mathrm{~b}$ illustrates that as the $\mathrm{MgO}$ increased from $1.36 \%$ to $3.10 \%$, the $\mathrm{RDI}_{+6.3}$ rose from $24.52 \%$ to $47.19 \%, \mathrm{RDI}_{+3.15}$ rose from $61.43 \%$ to $76.41 \%$ and $\mathrm{RDI}_{-0.5}$ fell from $7.58 \%$ to $3.38 \%$. For $\mathrm{RDI}_{+6.3}$ and 
$\mathrm{RDI}_{+3.15}$ of sinter in simulated COREX shaft furnace condition, their improvements were noticeable, especially after $\mathrm{MgO}$ content exceeded $2.10 \%$.
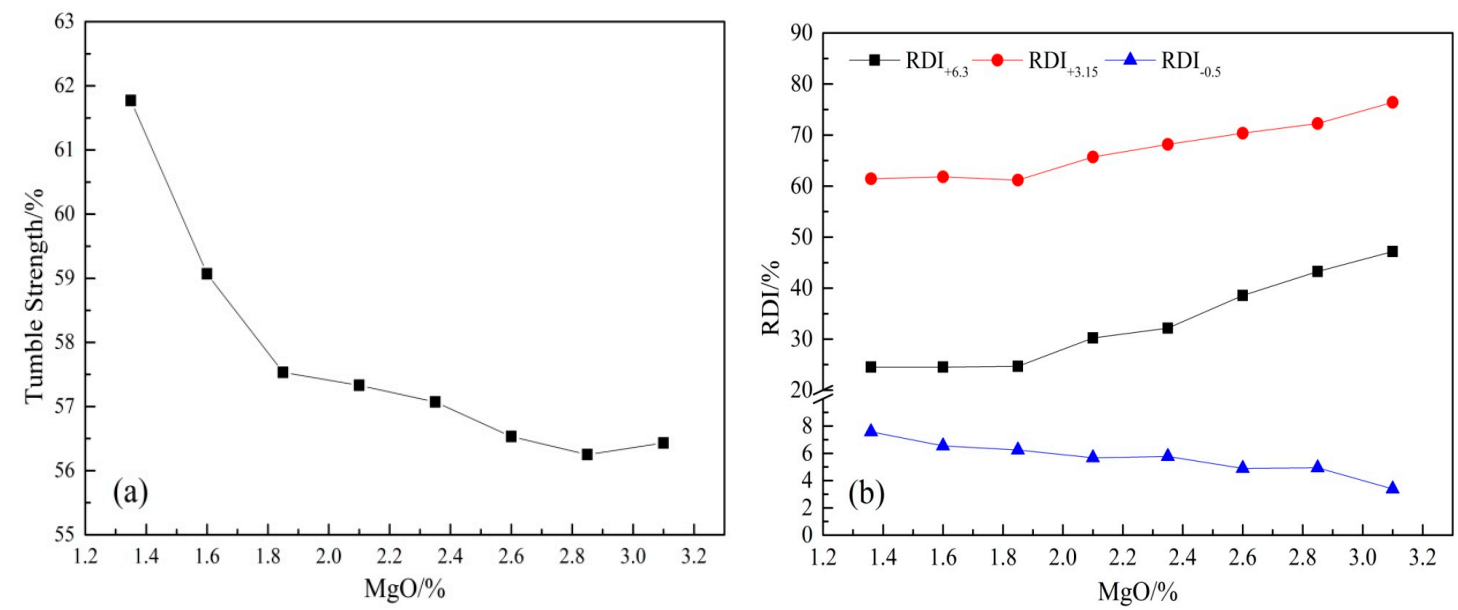

Figure 2. (a) Effects of $\mathrm{MgO}$ on cold strength of sinter; (b) effects of $\mathrm{MgO}$ on the RDI of sinter in reducing condition simulated COREX shaft furnace.

The results are similar to that in some previous researches concerning the effects of $\mathrm{MgO}$ on the strength of sinter, as well as RDI of sinter in the reduction process simulating BF process. The changes in mineral composition were recognized as the primary reason for the decline in tumble strength and improvement of low temperature degradation performance in most previous researches [10-14].

\subsection{Effect of $\mathrm{MgO}$ on the Reduction Degree and Reduction Rate of Sinter at Low Temperature}

After being reduced for $30 \mathrm{~min}$ in condition simulated COREX shaft furnace at low temperature $\left(550{ }^{\circ} \mathrm{C}\right)$, the reduction degree of sinter with different content of $\mathrm{MgO}$ is shown in Figure 3a. It shows that when the $\mathrm{MgO}$ content increased from natural to $3.10 \%$, the reduction degree of sinter at low temperature decreased from $5.99 \%$ to $2.80 \%$. Figure $3 \mathrm{~b}$ shows the changing reduction degree over time of sinter containing $1.36 \%, 2.35 \%$, and $3.10 \% \mathrm{MgO}$, respectively, from which the different reduction rates of sinter at low reducing temperature could be obtained through curve fitting. The fitting results suggest after the $\mathrm{MgO}$ content rose from $1.36 \%$ to $3.10 \%$, the reduction rate fell off from $0.2124 \% / \mathrm{min}$ to $0.1026 \% / \mathrm{min}$, decreased by more than $50 \%$.
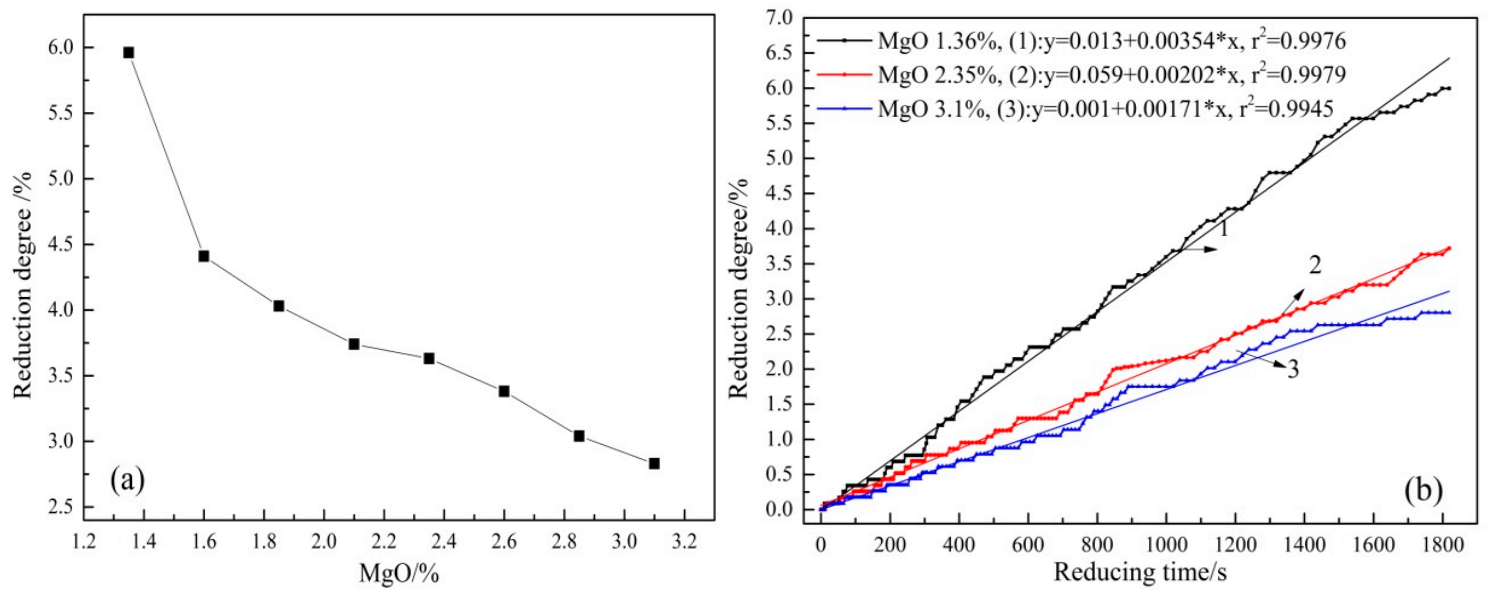

Figure 3. (a)Effects of $\mathrm{MgO}$ on reduction degree of sinter at low temperature in simulated COREX shaft furnace condition; (b) changing reduction degree over time of sinter. 
These results reveal that the reduction of sinter was apparently restrained by increasing $\mathrm{MgO}$ content. Previous research noted that the reduction of $\mathrm{Fe}_{2} \mathrm{O}_{3}$ to $\mathrm{Fe}_{3} \mathrm{O}_{4}$ dominates reducing reaction at $400-550^{\circ} \mathrm{C}$ for sinter in reducing condition simulated COREX shaft furnace [5]. This reaction was widely recognized as the root cause for reduction degradation of sinter, because volumetric expansion up to $25 \%$ occurred after the hematite $\left(\mathrm{Fe}_{2} \mathrm{O}_{3}\right)$ was reduced to magnetite $\left(\mathrm{Fe}_{3} \mathrm{O}_{4}\right)$ and generated significant inner-stress around reduced area in sinter, which would break the overall structure of sinter [8,9]. Thus, the suppression effect of increasing $\mathrm{MgO}$ content on reduction of sinter at low temperature could deservedly decrease the reducing innerstress and then improve the reduction degradation performance of sinter. In terms of the mechanism of suppression effect of $\mathrm{MgO}$ on reduction of sinter at low temperature, many relevant researches ascribed it to the changes in mineral composition, or rather in hematite quantity of sinter with increasing $\mathrm{MgO}$ content [11-13,15].

\subsection{Microstructure and Mineral Compositions of Sinter with Different Content of $\mathrm{MgO}$}

In order to clarify the effect of increasing $\mathrm{MgO}$ content on microstructure and mineral compositions of sinter, a series of tests were conducted in the present work. The microstructures of sinter with $1.36 \%$ and $3.10 \% \mathrm{MgO}$ are shown in Figure 4. It shows that the main mineral phase of the two sinter samples include magnetite, hematite, SFCA (silicoferrites of calcium and aluminum) and glass. It is notable that, according to morphological judgment, most of the hematite phase in sinter samples are secondary hematite, which deemed that it would aggravate the reduction degradation of sinter in earlier research work [7-9].

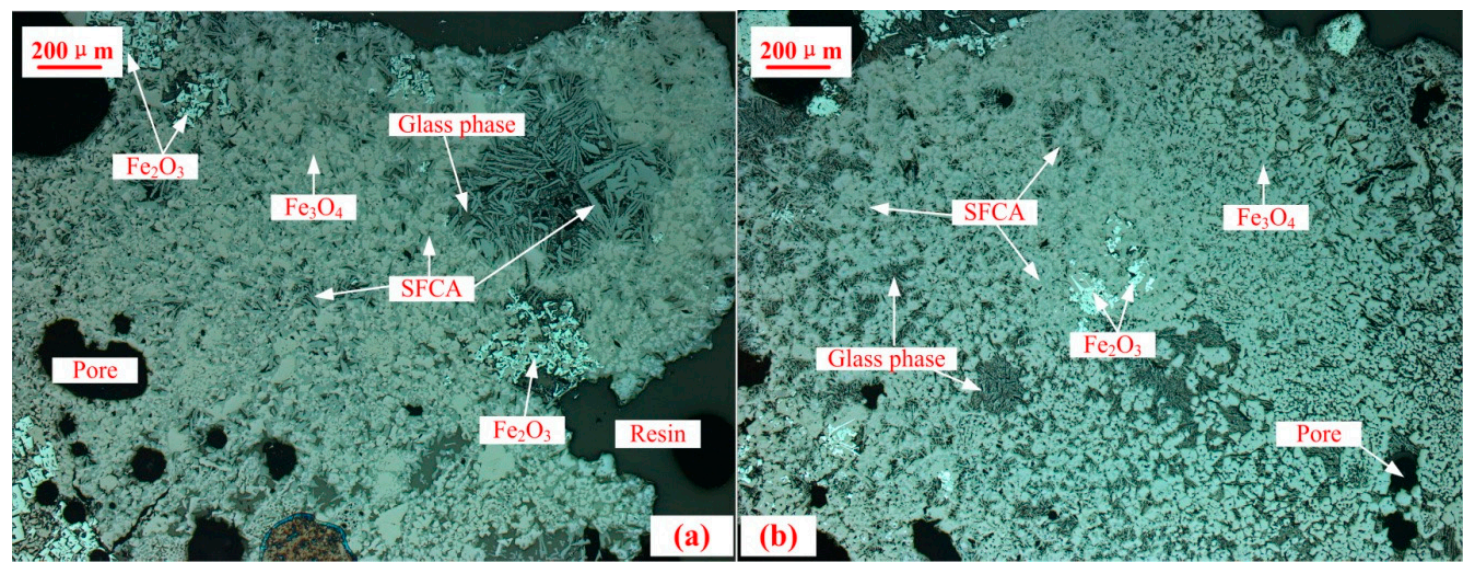

Figure 4. (a) Microstructures of sinter containing 1.36\% MgO; (b) microstructures of sinter containing $3.10 \% \mathrm{MgO}$.

An energy dispersive spectrometer (EDS) measured sinter sample with $3.10 \% \mathrm{MgO}$ and the results are shown in Figure 5. It indicates that the highest $\mathrm{Mg}^{2+}$ content distributed in the magnetite phase, a few $\mathrm{Mg}^{2+}$ distributed in SFCA and glass phase and no $\mathrm{Mg}^{2+}$ distributed in the hematite. Because $\mathrm{Mg}^{2+}$ has similar ionic radius with $\mathrm{Fe}^{2+}$, it's prone to diffuse into crystal lattice of magnetite by an isomorphism replacement with $\mathrm{Fe}^{2+}$. It makes magnetite more stable and depresses the oxidation of magnetite during cooling process in sintering [17-19]. Then, this will result in decreasing of hematite $\left(\mathrm{Fe}_{2} \mathrm{O}_{3}\right)$ in sinter, which was further confirmed by X-ray diffraction in this work. Figure 6 shows the XRD patterns of sinter samples with different content of $\mathrm{MgO}$. It suggests that, with the increase of $\mathrm{MgO}$ in sinter, the diffraction peaks of $\mathrm{Fe}_{2} \mathrm{O}_{3}\left(\right.$ at $24.2^{\circ}, 33.3^{\circ}, 41^{\circ}, 49.6^{\circ}, 54.2^{\circ}$, and $\left.64.2^{\circ}\right)$ was attenuated obviously, while the diffraction peaks of $\mathrm{Fe}_{3} \mathrm{O}_{4}$ keep relative sharp and intense. This could be regarded as a sign that the amount of $\mathrm{Fe}_{2} \mathrm{O}_{3}$ existing in sinter decreased when $\mathrm{MgO}$ content of sinter increased. 


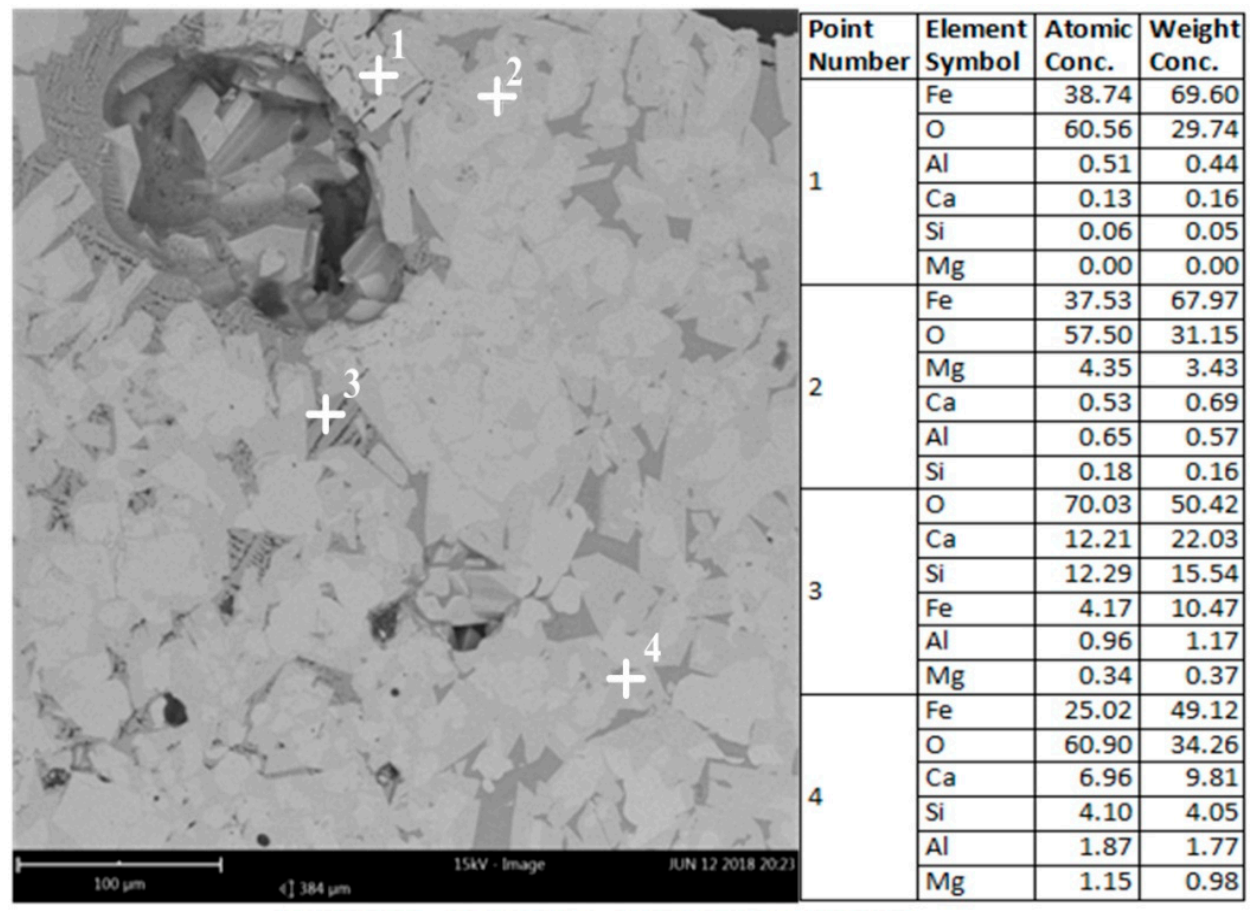

1-Hematite, 2-Magnetite, 3-Glass phase, 4-SFCA

Figure 5. Distribution of $\mathrm{MgO}$ in different minerals inside the sinter with $3.10 \% \mathrm{MgO}$.

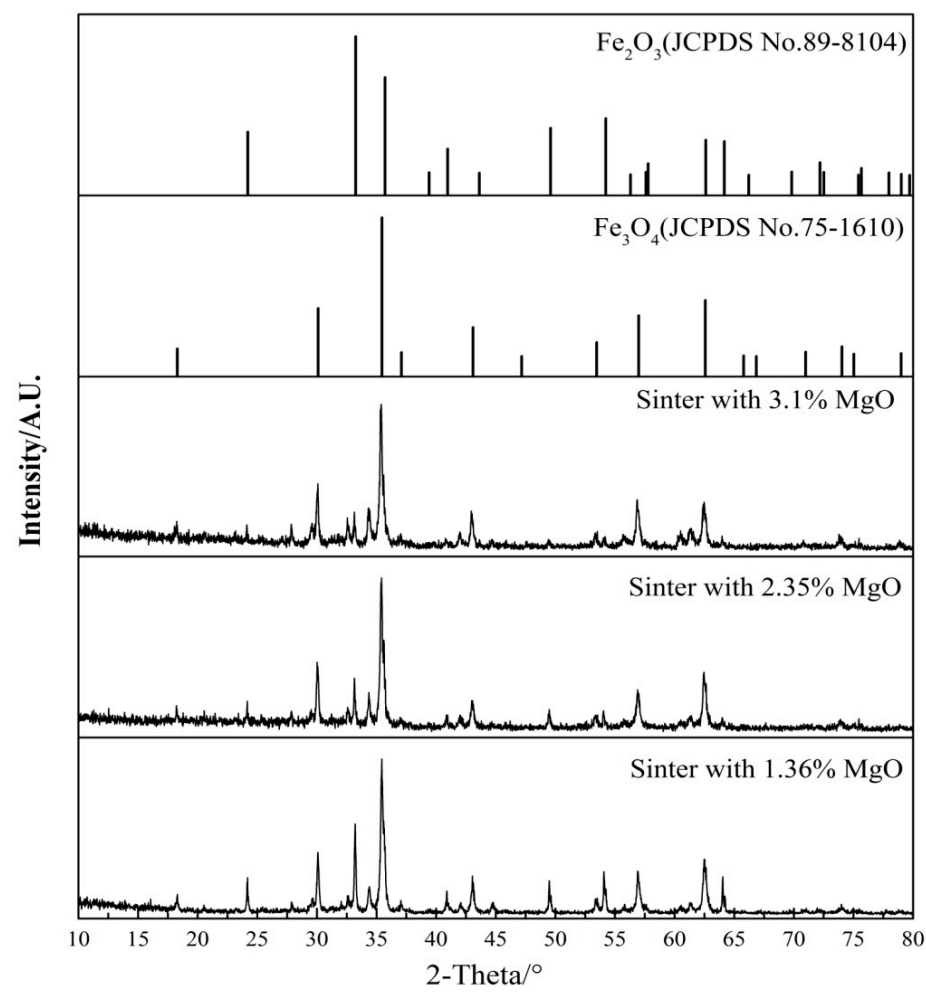

Figure 6. XRD patterns of sinter with different content of $\mathrm{MgO}$. 
Through image analysis by software QWin of Leica optical microscope, Table 1 further quantitatively shows the mineral compositions of sinter with $1.36 \%, 2.35 \%$, and $3.10 \% \mathrm{MgO}$ content, respectively. It reveals after $\mathrm{MgO}$ content of sinter rose to $3.10 \%$ from $1.36 \%$, the amount of hematite existing in product sinter decreased apparently, as well as the SFCA phase. Meanwhile, the quantity of magnetite and glass phase in product sinter kept rising with increasing $\mathrm{MgO}$ content. Besides, the porosity of sinter also increased slightly. The changes in quantity of hematite and magnetite accord well with above results of $\mathrm{X}$-ray diffraction tests.

Table 1. Mineral compositions of sinter with various $\mathrm{MgO}$ contents/area, \%.

\begin{tabular}{cccccc}
\hline MgO Content & Hematite & Magnetite & Glass Phase & SFCA & Porosity \\
\hline $1.36 \%$ & 15.37 & 32.02 & 11.73 & 25.56 & 14.96 \\
$2.35 \%$ & 13.58 & 34.45 & 14.83 & 21.06 & 16.08 \\
$3.10 \%$ & 7.25 & 40.27 & 15.96 & 19.63 & 16.89 \\
\hline
\end{tabular}

As is well known, SFCA acts as key bonding phase for fluxed sinter and its formation needs hematite. Given the depressing effect of $\mathrm{MgO}$ on formation of hematite during the cooling process, it is not surprising that fewer SFCA phase was observed in sinter with higher $\mathrm{MgO}$ content. That is the main reason for the decrease of sinter strength as Figure 2a shows. On the other hand, because the reduction of $\mathrm{Fe}_{2} \mathrm{O}_{3}$ to $\mathrm{Fe}_{3} \mathrm{O}_{4}$-which causes volumetric expansion and the generates considerable inner-stress in sinter-dominates reducing reaction of sinter at such reducing condition simulated COREX shaft furnace [5], the obvious decrease in hematite quantity could undoubtedly decrease the reduction degree at low temperature of sinter. Meantime, the probable reducing inner-stress generated during reduction was also decreased. Therefore, the improved reduction degradation performance of sinter is together decided, to some extent, by the effects of increasing $\mathrm{MgO}$ content on lowering sinter strength and inhibiting probable reduction of sinter at low temperature.

\subsection{Mineralogical Changes of Sinter with Different $\mathrm{MgO}$ Content after Reduction}

Figure 7 shows the XRD patterns of sinter samples with different $\mathrm{MgO}$ content after being reduced at $550{ }^{\circ} \mathrm{C}$ for $30 \mathrm{~min}$. It illustrates that there are no obvious distinctions in diffraction peaks of $\mathrm{Fe}_{3} \mathrm{O}_{4}$ in reduced sinter with different $\mathrm{MgO}$ content. However, in terms of $\mathrm{Fe}_{2} \mathrm{O}_{3}$, the situation is different. Compare with sinter containing natural $\mathrm{MgO}(1.36 \%)$, an obscure diffraction peak of $\mathrm{Fe}_{2} \mathrm{O}_{3}$ emerges at $24.2^{\circ}$ while a conspicuous diffraction peak emerges at $49.6^{\circ}$ in sinter containing $3.10 \% \mathrm{MgO}$. That implies more $\mathrm{Fe}_{2} \mathrm{O}_{3}$ have not been reduced and been remained in sinter with $3.10 \% \mathrm{MgO}$. In order to evaluate the proceeding extent for reaction of $\mathrm{Fe}_{2} \mathrm{O}_{3}$ to $\mathrm{Fe}_{3} \mathrm{O}_{4}$, the quantitative analysis of $\mathrm{Fe}_{2} \mathrm{O}_{3}$ and $\mathrm{Fe}_{3} \mathrm{O}_{4}$ in reduced sinter samples was made by software QWin of Leica optical microscope further. Figure 8 illustrates the comparisons of the amount of $\mathrm{Fe}_{2} \mathrm{O}_{3}$ in sinter samples containing various levels of $\mathrm{MgO}$ before and after reduction. During reduction process, the amount of $\mathrm{Fe}_{2} \mathrm{O}_{3}$ in sinter samples decreased by 14.35 percent points, 10.72 percent points, and 3.88 percent points successively. It means that less $\mathrm{Fe}_{2} \mathrm{O}_{3}$ has been reduced during experiments in sinter contains more $\mathrm{MgO}$. Because the reduction of $\mathrm{Fe}_{2} \mathrm{O}_{3}$ to $\mathrm{Fe}_{3} \mathrm{O}_{4}$ dominated reducing reaction at such condition presented in this work as noted, the least quantity of $\mathrm{Fe}_{2} \mathrm{O}_{3}$ that be reduced during the experiment inevitably brought the lowest reduction degree and reduction rate of sinter with $3.10 \%$. 


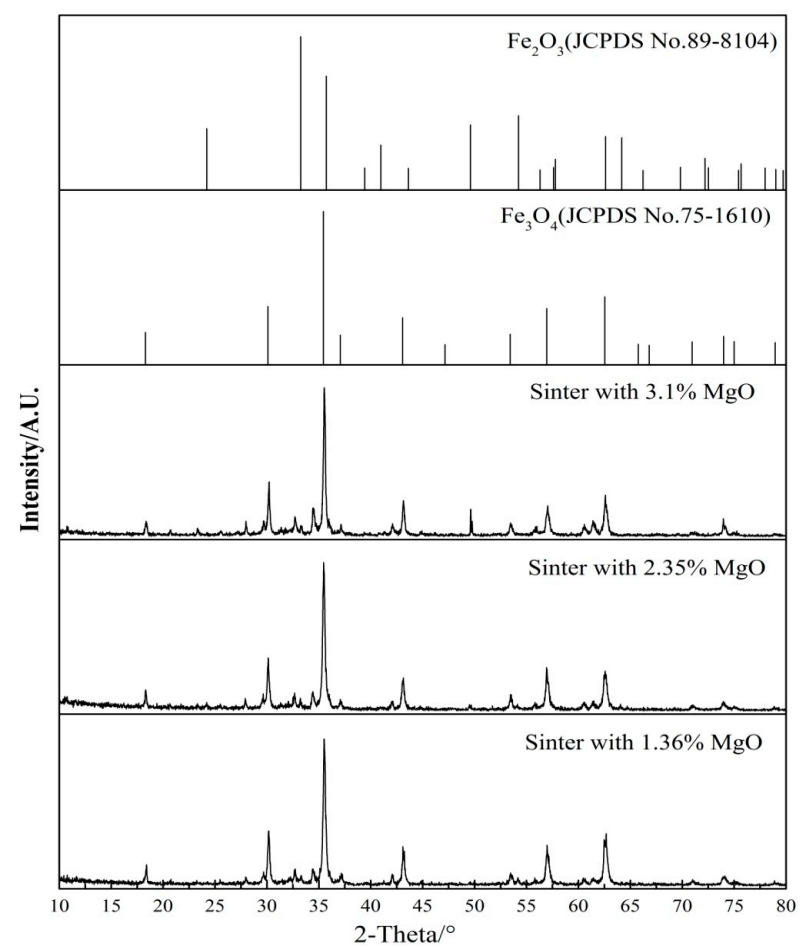

Figure 7. XRD patterns of sinter after reducing at $550{ }^{\circ} \mathrm{C}$ for $30 \mathrm{~min}$.

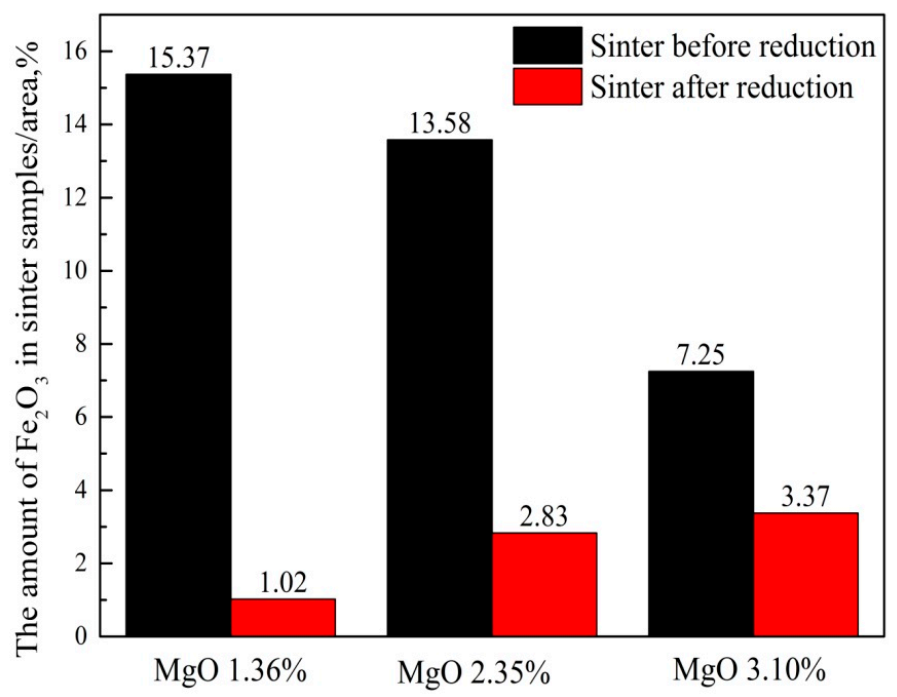

Figure 8. The amount of $\mathrm{Fe}_{2} \mathrm{O}_{3}$ in sinter samples containing various levels of $\mathrm{MgO}$.

Previous researches reported that reduction degradation of sinter begins with generation and development of cracks in sinter, which has significant influence on the final degradation degree of sinter $[8,17]$. Figure $9 \mathrm{a}-\mathrm{c}$, respectively, shows typical microstructure of sinter samples after reducing at $550{ }^{\circ} \mathrm{C}$ for $30 \mathrm{~min}$ and these sinter samples contain $1.36 \%, 2.35 \%$, and $3.10 \% \mathrm{MgO}$, respectively. They illustrate that cracks occurred in all sinter samples, but the situations depended on the MgO content of sinter to a great extent. Compared with the other two reduced sinter samples, wider cracks appear in large numbers, and widely distribute in all the mineral phases in outer and middle layers of sinter containing $1.36 \% \mathrm{MgO}$. The cracks interweave with each other especially in hematite (transforms to magnetite after reduction) clustered area. The cracks mainly distribute in the outer layers of sinter with $3.10 \% \mathrm{MgO}$. Then, further quantitative analyses of cracks density in reduced sinter were done and the result is shown in Figure 9d. It reveals that the cracks density of reduced sinter fell from $675.35 \mathrm{~m} \cdot \mathrm{m}^{-2}$ 
to $138.63 \mathrm{~m} \cdot \mathrm{m}^{-2}$ after the $\mathrm{MgO}$ content of sinter increased from $1.36 \%$ to $3.10 \%$. This gives evidence to that stronger inner-stress was generated and released in sinter contains $1.36 \% \mathrm{MgO}$ during low temperature-reduction process.

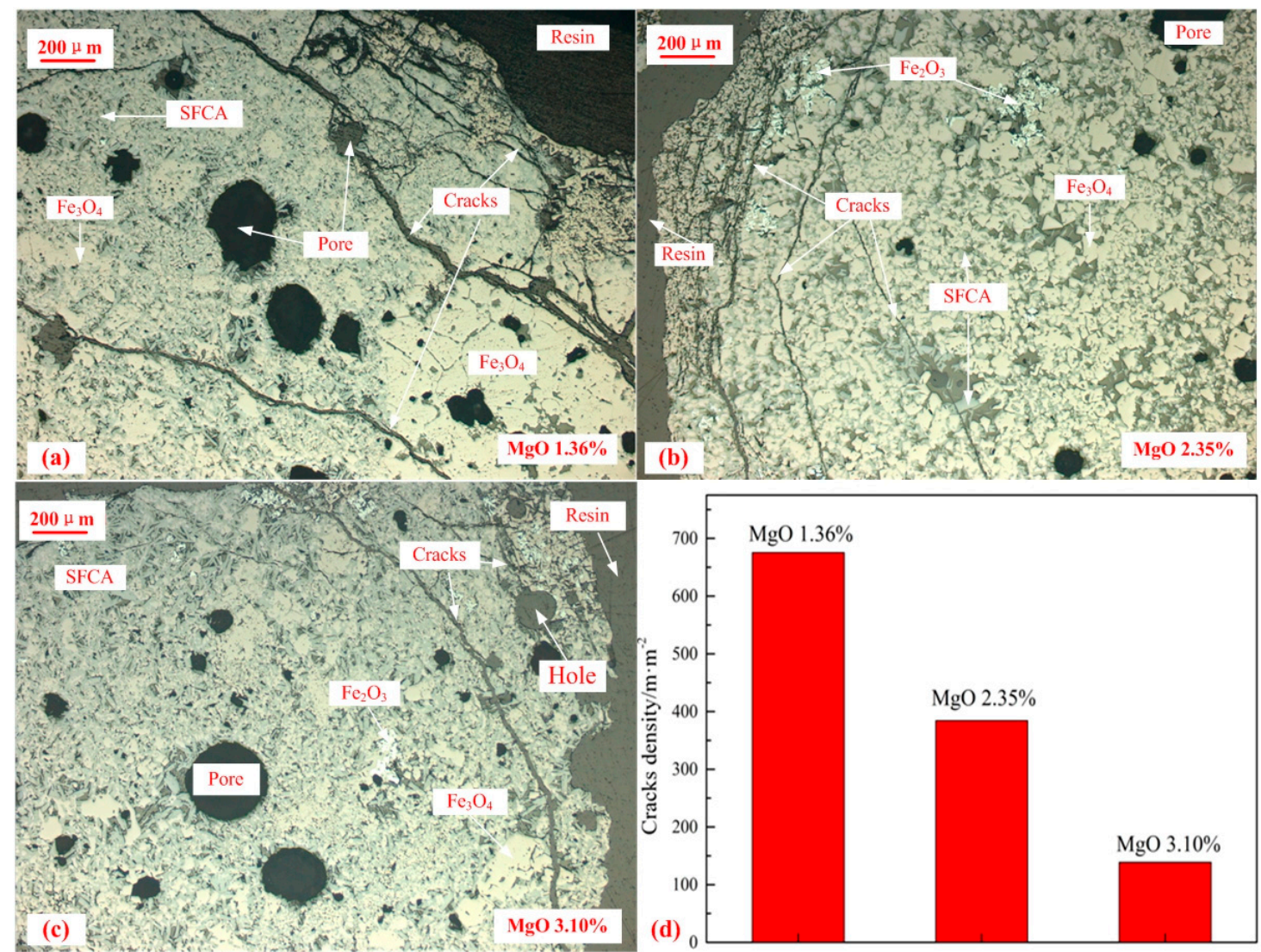

Figure 9. (a) Microstructure of reduced sinter containing 1.36\% MgO; (b) microstructure of reduced sinter containing $2.35 \% \mathrm{MgO}$; (c) microstructure of reduced sinter containing $3.10 \% \mathrm{MgO}$; and (d) crack density of reduced sinter with different $\mathrm{MgO}$ content.

According to relevant theory [8], the cracks formed in sinter soon after the start of the reduction. These cracks could provide access for reducing gas to diffuse into the inner parts of sinter and continuously reduce $\mathrm{Fe}_{2} \mathrm{O}_{3}$ to $\mathrm{Fe}_{3} \mathrm{O}_{4}$, and then new reducing reactions would generate new cracks. This cyclic process makes the cracks develop and extend. Based on the widespread and wider cracks in sinter with $1.36 \% \mathrm{MgO}$, it was suggested that reducing process proceeded deeper (corresponding to higher reduction degree at low temperature) and the cracks achieved greater development degree and then make the whole sinter structure to be distorted. While for sinter with $3.10 \% \mathrm{MgO}$, lower $\mathrm{Fe}_{2} \mathrm{O}_{3}$ phase content might lead to fewer cracks formed at the start of reduction and then the cyclic-reducing process might be limited in the beginning. Consequently, less cracks appeared in sinter with $3.10 \%$ $\mathrm{MgO}$ after reduction at low temperature.

\section{Conclusions}

This The influence of $\mathrm{MgO}$ on low temperature reduction behaviors and mineralogical changes of sinter before and after reduction were investigated in simulating COREX shaft furnace reducing conditions, and the conclusions were drawn as follows:

(1) As the $\mathrm{MgO}$ content of sinter increased from natural (1.36\%) to 3.10\%, the tumble strength of sinter decreased by 5.44 percentage points, while the $\mathrm{RDI}_{+6.3}$ of sinter increased nearly double. In the 
meantime, the reduction degree and at reduction rate at low temperature $\left(550{ }^{\circ} \mathrm{C}\right)$ both decreased by over $50 \%$.

(2) Increasing $\mathrm{MgO}$ content led to less $\mathrm{Fe}_{2} \mathrm{O}_{3}$ was observed in sinter. On the one hand, it led to fewer SFCA phase existed in sinter then decreased the sinter strength. On the other hand, it made the probable reducing inner-stress generated during low-temperature-reduction decrease. The improved $\mathrm{RDI}$ in COREX process of sinter by increasing its $\mathrm{MgO}$ content is a comprehensive result of lowering strength and inhibiting probable reduction of sinter.

(3) With increased $\mathrm{MgO}$ content, the proceeding extent of reducing reaction of $\mathrm{Fe}_{2} \mathrm{O}_{3}$ to $\mathrm{Fe}_{3} \mathrm{O}_{4}$ declined and less $\mathrm{Fe}_{2} \mathrm{O}_{3}$ in sinter was reduced during reduction process. Apart from lowering reduction degree and reduction rate at low temperature of sinter, it remarkably reduced the generation of inner-stress during low-temperature-reduction, which was confirmed by the decreased cracks density and cracks region.

Author Contributions: Data curation, J.P.; Investigation, J.C. and B.S.; Project administration, D.Z. and J.P.; Supervision, D.Z. and J.P.; Writing—original draft, B.S.; Writing—review \& editing, D.Z.

Funding: This research was funded by National Natural Science Foundation of China grant number [52574281] and Special Foundation for Innovation Drive Development of Guangxi Province grant number [GuiKe AA18242003].

Conflicts of Interest: The authors declare no conflict of interest.

\section{References}

1. Shalimov, A. The COREX process for making high-quality steels at mini-mills. Metallurgist 2000, 44, 35-39.

2. Kumar, P.P.; Barman, S.C.; Reddy, B.M.; Sekhar, V.R. Raw materials for COREX and their influence on furnace performance. Ironmak. Steelmak. 2009, 36, 87-90. [CrossRef]

3. Kumar, P.P.; Gupta, D.; Naha, T.K.; Gupta, S.S. Factors affecting fuel rate in COREX process. Ironmak. Steelmak. 2013, 33, 293-298. [CrossRef]

4. Guo, Y.L.; Xu, W.R.; Zhu, J.M.; Zhang, J.Y. The burden structure and its consumption in the melter gasifier of the COREX process. Metall. Mater. Trans. B 2013, 44, 1078-1085. [CrossRef]

5. Shi, B.J.; Zhu, D.Q.; Pan, J.; Xue, Y.X. Reduction behaviors of sinter made from magnetite concentrates in reducing process simulated COREX shaft furnace. In Proceedings of the 8th International Symposium on High-Temperature Metallurgical Processing, San Diego, CA, USA, 26 February-2 March 2017.

6. Tian, B.S.; Li, W.H. Production practice of blowing-in OY furnace of bayi steel. Xinjiang Iron Steel 2015, 4, 1-4.

7. Asada, M.; Shima, M.; Omori, Y. Measurement of macro strain in the course of reduction of the skeletal hematite in sinter(sinter). Phys. Rev. C 1984, 30, 1776-1778.

8. Loo, C.E.; Bristow, N.J. Mechanism of low-temperature reduction degradation of iron ore sinters. Trans. Inst. Min. Metall. Sect. C 1994, 103, 126-135.

9. Nakajima, R.; Sumigama, T.; Wakimoto, K.; Nagano, S.; Kawata, H.; Sakurai, M. Reduction Degradation behavior of sinter in the blast furnace shaft (blast furnace phenomena). Tetsu-to-Hagane 1987, 73, 1964-1971. [CrossRef]

10. Panigrahy, S.C.; Verstraeten, P.; Dilewijns, J. Influence of $\mathrm{MgO}$ addition on mineralogy of iron ore sinter. Metall. Trans. B 1984, 15, 23-32. [CrossRef]

11. Jiang, X.; Wu, G.S.; Guo, W.; Li, X.G.; Shen, F.M. Effect of $\mathrm{MgO}$ on sintering process and metallurgical properties of sinter. Iron Steel 2006, 41, 1-5.

12. Zhang, M.; Andrade, M.W. Effect of $\mathrm{MgO}$ and basicity on microstructure and metallurgical properties of iron ore sinter. In Characterization of Minerals Metals and Materials John; Springer: Cham, Switzerland, 2016.

13. Gan, Q.; He, Q.; Wen, Y.C. Study on influence of $\mathrm{MgO}$ on mineral composition and metallurgical properties of V-bearing titaniferous magnetite sinter. Iron Steel 2008, 43, 7-11.

14. Guo, Y.F.; Guo, X.M. Effect of $\mathrm{MgO}$ on low temperature reduction process of hematite fines sinter. J. Iron Steel Res. 2017, 29, 697-703.

15. Pan, J.; Shi, B.J.; Zhu, D.Q.; Mo, Y.P. Improving sintering performance of specularite concentrates by pre-briquetting process. ISIJ Int. 2016, 56, 777-785. [CrossRef]

16. Shi, B.J.; Zhu, D.Q.; Pan, J.; Liu, X.Q. Combined effect of $\mathrm{MgO}$ and basicity varied by different dolomite and burnt lime addition on sintering performance of magnetite concentrates. Ironmak. Steelmak. 2019. [CrossRef] 
17. Yadav, U.S.; Pandey, B.D.; Das, B.K.; Jena, D.N. Influence of magnesia on sintering characteristics of iron ore. Ironmak. Steelmak. 2002, 29, 91-95. [CrossRef]

18. Fan, X.H.; Li, W.Q.; Gan, M.; Chen, X.L.; Yuan, L.S.; Ji, Z.Y.; Yu, Z.Y.; Huang, X.X.; Su, D. Influence and mechanism of $\mathrm{MgO}$ on strength of high basicity sinter. J. Cent. South Univ. 2012, 43, 3325-3330.

19. Li, Q.; Huang, Z.C.; Jiang, T.; Yang, Y.B.; Li, G.H. Effect of dolomite and serpentine on sinter quality and microstructure. Iron Steel 2006, 41, 10-14.

C 2019 by the authors. Licensee MDPI, Basel, Switzerland. This article is an open access article distributed under the terms and conditions of the Creative Commons Attribution (CC BY) license (http://creativecommons.org/licenses/by/4.0/). 